\title{
Immunoprophylaxis against respiratory syncytial virus with palvizumab: what is new?
}

\author{
Imunoprofilaxia do vírus sincicial respiratório com palivizumabe: o que há de novo? \\ Inmunoprofilaxis del virus sincitial respiratorio con palivizumabe: ¿qué novedades hay?
}

Marco Aurélio P. Sáfadi ${ }^{1}$

Infection by the respiratory syncytial virus (RSV) is recognized as the most important cause of respiratory tract infection in infants and young children in the world, being the main responsible for hospitalizations during winter in the first year of life ${ }^{(1)}$. However, despite the importance of RSV as a cause of morbidity and mortality in children, there are still no effective vaccines or antiviral drugs to prevent and treat this infection. The disastrous experience with an inactivated vaccine candidate made with whole virus, developed in the sixties, still unrests the medical community in the search for a safe and effective vaccine against RSV infection ${ }^{(2)}$. The possibility of preventing the infection by RSV gained even more importance in the last 10 years, due to the accumulation of evidence showing that hospitalized infants with lower respiratory tract infection (especially those caused by RSV and rhinovirus) are at greater risk of developing recurrent episodes of wheezing and asthma, when compared to children that did not present severe bronchiolitis ${ }^{(3-5)}$.

Passive immunization with palivizumab, a humanized monoclonal antibody, is currently the main tool available for the prophylaxis of RSV infection. Its use is indicated for specific risk groups: preterm infants and children under 2 years old with congenital heart disease and hemodynamic repercussion or with chronic pulmonary disease, who needed treatment in the 6 months prior to the season of $\mathrm{RSV}^{(6)}$. However, the impact of this intervention in the burden of the disease attributable to RSV is minimal, once most hospitalizations due to the virus occur in healthy infants, who are not included in prevention programs.
The current edition of the Journal includes an article by Monteiro $e t a^{(7)}$, which presents results of a study including a cohort of 198 infants who received palivizumab, according to the recommendations in the state of São Paulo, Southeast Brazil. Infants were followed prospectively during a year, to assess the impact of palivizumab on the viral etiology of acute infections in the respiratory tract and rates of hospitalization and death. It is remarkable, among the various important findings, the rate of only $0.7 \%$ of hospitalization by RSV in infants undergoing immunoprophylaxis (only one hospitalization by RSV among the 198 followed infants). One of the limitations of the study, pointed by the authors, was the lack of a control group, for ethical reasons, which prevented the assessment of the effectiveness of the intervention with immunoprofilaxys in the studied group.

There is today a growing debate regarding the scope of indications for the use of palivizumab, motivated not only by the high cost of the product, but also by recent evidence in the literature. The licensing of palivizumab, in the late 1990s, was based on the results of a randomized, placebocontrolled study with 1,500 preterm infants, which showed that immunoprofilaxys reduced in approximately $55 \%$ the rates of hospitalization by RSV (10.6\% in the Placebo Group against $4.8 \%$ among high-risk infants who received palivizumab $^{(8)}$. However, more recent data ${ }^{(9-11)}$ suggest that the RSV hospitalization rates among preterm infants belonging to risk groups present a trend towards reduction in relation to the rates found in the studies conducted in the 1990s, in line with the results by Monteiro et al in Brazil.
Instituição: Faculdade de Ciências Médicas da Santa Casa de São Paulo (FCMSCSP), São Paulo, SP, Brasil

${ }^{1}$ FCMSCSP, São Paulo, SP, Brasil
Endereço para correspondência:

Marco Aurélio P. Sáfadi

Rua Afonso Braz, 579, cj. 45

CEP 04511-011 - São Paulo/SP

E-mail: masafadi@uol.com.br

Conflito de interesse: nada a declarar

Recebido em: 7/3/2014 
The confirmation of lower rates of de hospitalization by RSV in preterm infants currently brings a new challenge for the analysis of the cost-effectiveness demonstration of this intervention, requiring an even higher number on infants covered with immunoprofilaxys to enable the prevention of one RSV hospitalization. On the other hand, there is increasing evidence suggesting that the use of palivizumab in children reduces the incidence of future episodes and days of wheezing ${ }^{(12,13)}$, anticipating the possibility of additional benefits, not incorporated

\section{References}

1. Hall CB, Weinberg GA, Iwane MK, Blumkin A, Edwards KM, Staat M et al. The burden of respiratory syncytial virus infection in young children. $\mathrm{N}$ Engl $\mathrm{J}$ Med 2009;360:588-98.

2. Chin J, Magoffin RL, Shearer LA, Schieble JH, Lennette EH. Field evaluation of a respiratory syncytial virus vaccine and a trivalent parainfluenza virus vaccine in a pediatric population. Am J Epidemiol 1969;89:449-63.

3. Stein RT, Sherrill D, Morgan WJ, Holberg CJ, Halonen M, Taussig LM et al. Respiratory syncytial virus in early life and risk of wheeze and allergy by age 13 years. Lancet 1999;354:541-5.

4. Sigurs N, Gustafsson PM, Bjarnason R, Lundberg F, Schmidt S, Sigurbergsson $\mathrm{F}$ et al. Severe respiratory syncytial virus bronchiolitis in infancy and asthma and allergy at age 13. Am J Respir Crit Care Med 2005;171:137-41.

5. Calıskan M, Bochkov YA, Kreiner-Møller E, Bonnelykke K, Stein M, Du G et al. Rhinovirus wheezing illness and genetic risk of childhood-onset asthma. N Engl J Med 2013;368:1398-407.

6. AAP Committee on Infectious Diseases. Respiratory syncytial virus. In: Pickering LK, Baker CJ, Kimberlin DW, Long SS, editors. Red Book: Report of the Committee on Infectious Diseases. 29th ed. Elk Grove Village, IL: American Academy of Pediatrics; 2012. p. 609-18.

7. Monteiro AI, Bellei NC, Sousa AR, Santos AM, Weckx LY. Infecções respiratórias em crianças menores de dois anos de idade submetidas à profilaxia com palivizumabe. Rev Paul Pediatr 2014;32:152-8. into cost-effectiveness and that, if confirmed in other populations, may change the scenario of the prevention of the infection by RSV.

Finally, we emphasize that there is no evidence so far in the literature to support the extending use of palivizumab to other groups, such as patients presenting cystic fibrosis, those immunocompromised, and patients with Down syndrome, nor to support its use to control outbreaks in Neonatal Intensive Care Units. Therefore, palivizumab does not have indication for routine use in these situations ${ }^{(14)}$.

8. Autoria não referida. Palivizumab, a humanized respiratory syncytial virus monoclonal antibody, reduces hospitalization from respiratory syncytia virus infection in high-risk infants. The IMpact-RSV Study Group. Pediatrics 1998;102:531-7.

9. Zhou H, Thompson W, Viboud C, Ringholz C, Cheng PY, Steiner C et al Hospitalizations associated with influenza and respiratory syncytial virus in the United States, 1993-2008. Clin Infect Dis 2012;54:1427-36.

10. Paes B, Mitchell I, Li A, Harimoto T, Lanctôt KL. Respiratory-related hospitalizations following prophylaxis in the Canadian registry for palivizumab (2005-2012) compared to other international registries. Clin Dev Immuno 2013;2013:917068.

11. Hasegawa K, Tsugawa Y, Brown DF, Mansbach JM, Camargo CA. Trends in bronchiolitis hospitalizations in the United States, 2000-2009. Pediatrics 2013;132:28-36.

12. Yoshihara S, Kusuda S, Mochizuki H, Okada K, Nishima S, Simões EA C-CREW Investigators. Effect of palivizumab prophylaxis on subsequent recurrent wheezing in preterm infants. Pediatrics 2013;132:811-8.

13. Blanken MO, Robers MM, Molenaar JM, Winkler-Seinstra P, Meijer A, Kimpen $\mathrm{JL}$ et al. Respiratory syncytial virus and recurrent wheeze in healthy preterm infants. N Engl J Med 2013;368:1791-9.

14. Meissner HC, Kimberlin DW. RSV immunoprophylaxis: does the benefit justify the cost? Pediatrics 2013;132:915-8. 